imágenes de interés

\title{
Cintigrama com leucócitos marcados numa situação de megacolon toxico \\ ${ }^{99 m}$ Tc-HMPAO leukocyte scan and toxic megacolon
}

A Doménech, M J Cunha, L Pereira, A Ferrer-Antunes, J Isidoro, J LimA

Serviço de Medicina Nuclear dos Hospitais da Universidade de Coimbra. Portugal.

\section{CASO CLÍNICO}

Doente do sexo feminino, de 15 anos de idade, que recorreu ao Serviço de Urgência com quadro de dia-

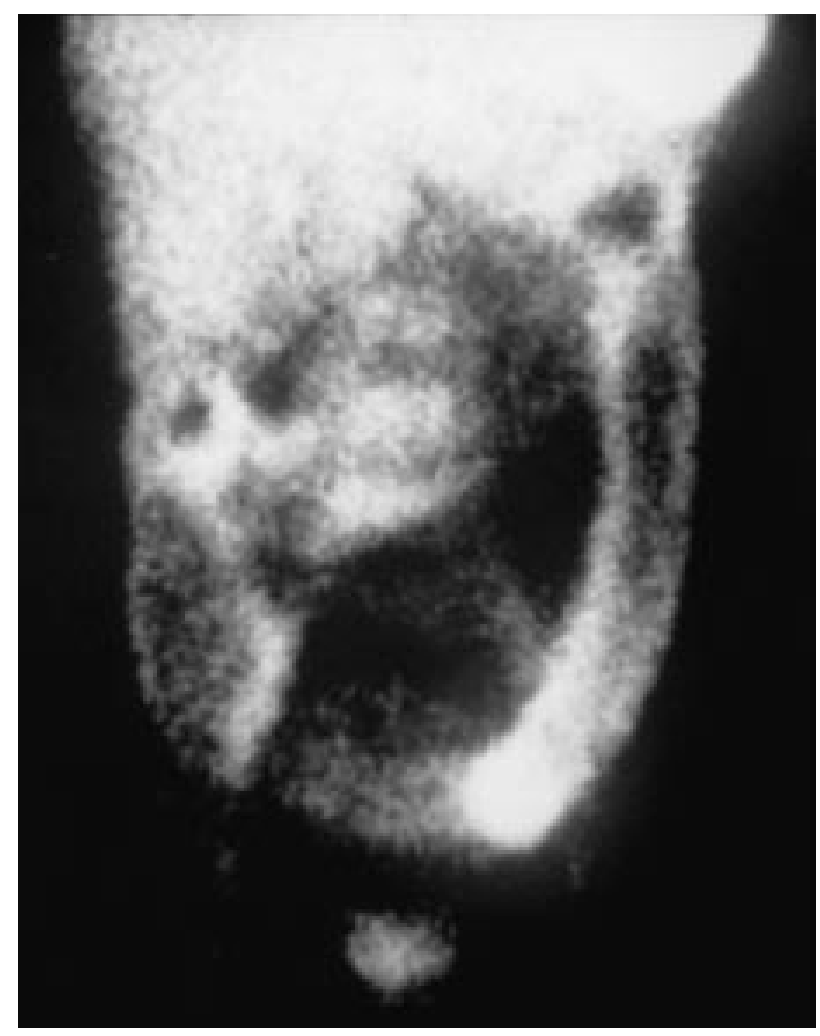

FIG. 1.-Cintigrafia: Imagem dos 30 minutos.

Recibido: 29-04-00.

Aceptado: 18-05-00.

Correspondencia:

A DOMÉNECH

Praceta Prof. Mota Pinto, s/n.

3000-Coimbra, Portugal

E-mail: smnhuc@mail.telepac.pt rreia, febre e anemia, sendo internada para estudo. No dia do internamento fez ecografia que não revelou alterações significativas e pansigmoidoscopia com biópsia, que mostrou quadro de colite severa com morfologia da mucosa sugestiva de colite ulcerosa.

Durante o internamento realizaram-se hemocultura, diversos estudos serológicos e exames parasitológicos das fezes, todos eles negativos. No quarto dia de internamento iniciou quadro de toxicidade sistémica. $\mathrm{Na}$

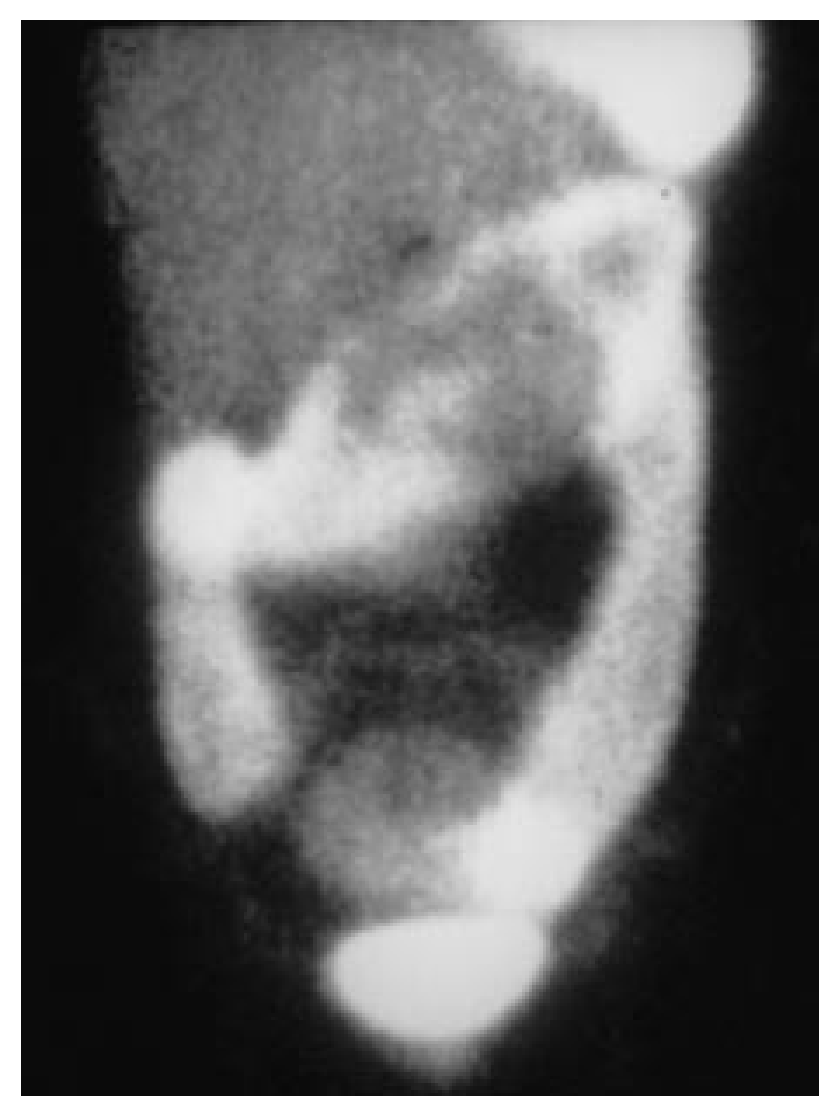

FIG. 2.—Cintigrafia: Imagem das 2 horas. 
ecografia realizada observou-se a existência de ansas distendidas, com líquido no seu interior e acentuada adinamia a nível do cólon ascendente. Foi realizado cintigrama com leucócitos marcados com ${ }^{99 \mathrm{~m}} \mathrm{Tc}-\mathrm{HM}-$ PAO (Figs. 1 y 2) que mostrou marcada hipercaptação ao longo do todo o cólon, com aumento das suas dimensões, compatível com quadro de megacólon tóxico.

Fez tratamento com antibióticos, corticoides, ciclosporina e.v. e outras medidas terapêuticas, com melhoria dos parâmetros inflamatórios e desaparecimento da dilatação cólica. Teve alta para o domicilio 35 dias após o internamento.

\section{BIBLIOGRAFÍA}

Prats E, Banzo J, Nerin J, Freile E, Lopez Zaborras J. Toxic megacolon detected by ${ }^{99 \mathrm{~m}} \mathrm{Tc}-\mathrm{HMPAO}$ mixed leukocyte scan. Clin Nucl Med. 1991;16(5):365-6. 